\title{
REVIEW
}

\section{IMPACT OF DAMS AND IRRIGATION SCHEMES IN ANOPHELINE (DIPTERA: CULICIDAE) BIONOMICS AND MALARIA EPIDEMIOLOGY}

\author{
Jordi SANCHEZ-RIBAS(1,3), Gabriel PARRA-HENAO(2) \& Anthony Érico GUIMARÃES(3)
}

\begin{abstract}
SUMMARY
Irrigation schemes and dams have posed a great concern on public health systems of several countries, mainly in the tropics. The focus of the present review is to elucidate the different ways how these human interventions may have an effect on population dynamics of anopheline mosquitoes and hence, how local malaria transmission patterns may be changed. We discuss different studies within the three main tropical and sub-tropical regions (namely Africa, Asia and the Pacific and the Americas). Factors such as prehuman impact malaria epidemiological patterns, control measures, demographic movements, human behaviour and local Anopheles bionomics would determine if the implementation of an irrigation scheme or a dam will have negative effects on human health. Some examples of successful implementation of control measures in such settings are presented. The use of Geographic Information System as a powerful tool to assist on the study and control of malaria in these scenarios is also highlighted.
\end{abstract}

KEYWORDS: Malaria transmission; Anopheles bionomics; Water development project; Control.

\section{INTRODUCTION}

As a result of human expansion through the world and environmental modifications to satisfy our necessities, new interactions between us and the environment have emerged, leading to new epidemiological patterns of the main vector-borne diseases ${ }^{63}$. Mainly in Africa, Asia and the Pacific and the Americas, irrigation schemes and dams have extensively proliferated to cover the growing food and energetic demands of these regions ${ }^{99}$. It is estimated that a total of 18,3 million people live within $2 \mathrm{~km}$ of the shoreline of a dam and other 851,3 million people inhabit areas in close proximity to irrigation schemes in malaria-endemic areas ${ }^{49}$.

Although not always the case, there is growing evidence that demographic movements coupled with environmental alterations may favour the proliferation of vector-borne diseases, the main ones being malaria, lymphatic filariasis, Japanese B encephalitis and onchocerciasis $^{42}$. Over these diseases, malaria poses the major threat to public health, with approximately 190 and 311 million clinical cases per year, and accounting for between 708,000 and 1,003,000 deaths annually, mainly in sub-Saharan Africa ${ }^{15}$. The high adaptability of some malaria vectors, control program problems such as difficulties in implementation, financial sustainability and poor population adherence to control measures coupled with other factors outside of the health sector, constitute a threat to public health in water development projects (WDP) of many developing countries $^{60}$. For these reasons, we chose irrigation schemes and dams and their effect on Anopheles population dynamics and malaria transmission as the focus for this review.

\section{SEARCH STRATEGY}

We searched for articles mostly through PubMed using key words such as "malaria", "Anopheles", "dams", "irrigation schemes", "environmental impact", "ricefields". A critical selection of informative studies was made and extra references were included from World Health Organization (WHO) publications and various online resources and books on Anopheles and malaria. Seventy-one studies published presenting original data in international peer-reviewed journals were included. Also, we considered for this publication ten previous reviews on the topic of modified environments and their effect on malaria epidemiology.

Different types of study design exist to evaluate the impact of WDP on malaria. The best approach to characterize their direct effect is provided by studies that compare data on Anopheles bionomics or malaria transmission before and after human intervention. However, these types of studies are not the most common, due to limitations such as the absence of reliable information on the pre or post intervention scenario. An alternative approach is to compare the prevalence or incidence of malaria between communities under WDP influence and others nearby, 


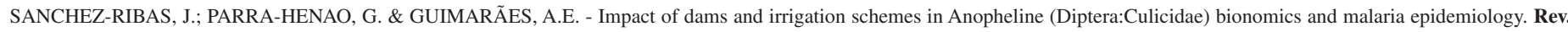
Inst. Med. Trop. Sao Paulo, 54(4): 179-91, 2012.

used as controls. The latter must present similar characteristics to the former to validate these comparisons and minimize the effect of confounders. Although less conclusive, a third alternative is to use only post-intervention data, and compare it to other parts of the country. All three study designs were considered in this review.

\section{WATER DEVELOPMENT PROJECTS AND MALARIA}

Malaria manifestations in each community, region or country are defined by the interaction in time and space of intrinsic (human, parasite and mosquito) and extrinsic (environmental and socio-economical conditions, human behaviour and control measures) determinants of the disease ${ }^{11}$. For example, population relocations into new areas of irrigation or dam construction can draw two types of scenarios with different epidemiological significance. Firstly, there could be an introduction of Plasmodium parasites into free-malaria areas by immigrant workers coming from other endemic regions and secondly, non-immune populations could be exposed to malaria after moving into transmission areas ${ }^{43}$. Due to the high complexity of the factors that modulate malaria transmission, it is necessary to conduct site-specific studies to research on the contextual determinants of the disease and hence consistently evaluate the impact that each WDP has on the local malaria epidemiological pattern.

\section{DAMS}

With the discovery of the turbine in 1832 , the era of the big dams constructed mainly for hydropower generation started, triggering the construction of mega-dams during the 1930s. The majority of the rivers have been dammed and hydropower energy represents the $13 \%$ of the total electrical power generated in USA, 99\% in Norway, $75 \%$ of New Zealand and $70 \%$ of Latin America ${ }^{48}$. Brazil, China, Colombia, India, Peru and Congo are the countries with the greatest hydroelectric potential unexploited, with the Amazon, Congo and Mekong basins being the ones that can be exploited best for this purpose ${ }^{42} .40,000$ large dams and other 800,000 man-made lakes of smaller size were estimated to have been built by $2001^{49}$.

\section{AFRICA}

When looking at the effect of WDP on malaria, it is important to establish if a stable or unstable transmission pattern in the area exists. This factor will determine, to a great extent, if the WDP will have a positive or negative effect, or no effect at all, on malaria incidence. Stable malaria transmission areas are characterised by high infant mortality and also high levels of acquired immunity due to the vast levels of disease exposure. In these areas, transmission levels are high and without marked fluctuations in incidence over time. In contrast, areas with irregular transmission between months and years and with markedly lower transmission rates are classified as unstable. In such epidemiological settings, epidemics are common and all age groups may be evenly affected, resulting from the lower acquired immunity of these populations ${ }^{16}$.

Human environmental modifications normally exert a great impact on unstable areas, most of the times in form of epidemics with high morbidity and mortality rates ${ }^{61}$. Nevertheless, this is not always the case, like in the Gleita dam constructed in an area of unstable malaria transmission of Mauritania, where the malaria incidence was not enhanced ${ }^{6}$. On the other hand, stable areas sustain the capacity to better absorb the artificial alterations, resulting in small effects on the per se very high malaria exposure $^{61}$.

Anopheles gambiae s.s, An. arabiensis (both pertaining to the same species complex) and An. funestus are considered the three main malaria vectors in sub-Saharan Africa. The members of the gambiae complex have been recorded extensively both in man-made lakes and flooded ricefields. The presence of An. funestus in such artificially altered environments has been less studied. However, the occurrence of this species in flooded paddy fields may be expected, as its larvae have been associated with permanent breeding sites with emerging vegetation ${ }^{32}$.

Pre- and post-intervention data demonstrated that the construction and operation of two large dams in the Senegal River, increased anopheline densities but without exerting any significant influence on malaria transmission. This could be explained because exacerbated mosquito densities were not accompanied by favourable conditions to allow the female mosquitoes to live long enough to become infected, permit the complete Plasmodium development cycle to take place inside them and transmit the disease to another susceptible host ${ }^{18}$.

Although much attention has been given to large dams (defined as having more than 15 meters high or more than three million $\mathrm{m}^{3}$ of water storage capacity ${ }^{49}$ ) it is highly probable that small dams may pose a greater impact on malaria transmission. These "micro-dams" are developed at much greater rate and their surveillance and control is more difficult when compared with the big projects ${ }^{60}$. The shoreline of a man-made lake is considered the main mosquito producing area. For this reason, a group of small dams will have a total shoreline length much more extensive than a unique big dam, but with the equivalent water surface. So, micro-dams will have a higher potential for mosquito production and may become an important source of health risk ${ }^{90}$. The region of Tigray in northern Ethiopia constitutes a prime example of the effect of micro-dams in exacerbating malaria incidence in an unstable transmission area. Communities in the vicinity of the micro-dams presented a seven fold higher transmission rate than control villages. This increase was of special concern because before the implementation of the microdams, low transmission levels existed in the area, and thus low acquired immunity levels in the local population also existed ${ }^{29}$. More examples of impoundments and malaria are found in Ethiopia. For example, the construction of the Koka dam was also associated with increased levels of malaria transmission and with P. falciparum becoming more prevalent in communities adjacent to the dam $\operatorname{sit}^{55}$. Similarly, YEWHALAW et $a l .{ }^{101}$ observed a higher proportion of $P$. vivax infections on children living in communities near the Gilgel-Gibe dam, but the proportions of $P$. falciparum cases were not significantly different for at-risk communities and villages farther away. Finally, transmission enhancement was also verified in communities close to the Bamendjin dam in Cameroon ${ }^{3}$.

\section{ASIA AND THE PACIFIC}

Some reports demonstrate how dam construction can exert influence on increasing malaria transmission levels in Asia. The Bargi dam is a well documented example of this case, which facilitated a malaria epidemic in 1996 with high mortality rates and increased proportion of $P$. falciparum infections ${ }^{81}$. Also in India, the Sardar Sarovar artificial lake favoured a sharp increase in malaria transmission ${ }^{80}$. 


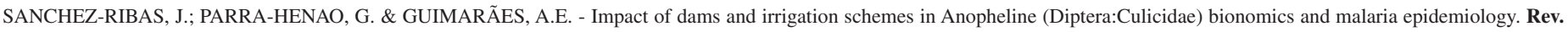
Inst. Med. Trop. Sao Paulo, 54(4): 179-91, 2012.

In contrast with the case of the micro-dams in the Tigray region of Ethiopia, similar small-WDP was associated with an amelioration of malaria in the Orissa region of India. Pre-intervention surveys yielded 1304 cases per 1000 people/year and after the implementation of the micro-dams this index dropped to 181.1 cases per 1000 people/year. In this area the main vector was An. fluviatilis, a highly antropophilic species and with preference to breed in slow flow streams. The construction of small dams impeded the natural flow of the streams, thus converting the area in an inhospitable breeding ground for this vector ${ }^{76}$.

In the neighbouring Bangladesh, an unstable malaria transmission pattern exists, with $P$. vivax being the predominant parasite species and transmitted by the local malaria vector, An. philippinensis. With the construction of several dams for flood control of the lowland areas the abundance of this vector diminished steadily and, consequently, the risk of acquiring malaria also diminished. This phenomenon could be explained by the direct removal of natural breeding sites and by the high concentrations of organic matter of the new water bodies, factors that normally prejudice Anopheles proliferation?.

In Southeast Asia, dams and irrigation schemes have been extensively implemented. Intense deforestation aimed to implant these projects led to the marked reduction of the highly efficient forest malaria vector $A n$. dirus. However, some of these new scenarios were well colonized by another local efficient vector, An. minimus ${ }^{60}$. The Srinagarind dam is one of the few examples that documented the effect of a dam on malaria in this region. An. minimus, An. balabacensis and An. maculatus thrived in this new artificial water body, resulting in transmission enhancement ${ }^{12}$.

\section{LATIN AMERICA}

The Amazon is vast and ecologically very complex, comprising an irregular distribution of malaria prevalence, with the highest indices usually concentrated in settlements of frontier areas. Environmental alterations due to diverse human activities and asymptomatic parasite carriage have been postulated as the two major factors implied in the maintenance and recrudescence of malaria transmission in this huge tropical region ${ }^{77}$. In the Neotropics, most studies relating dams and malaria have been carried out in Brazil, which possesses one of the biggest hydroelectrical potentials in the world, as most of the Amazon basin is contained within its borders. The Brazilian electrical system is largely sustained by hydropower generating dams which may disrupt the ecological equilibrium in many areas, directly affecting human health. Brazilian dams are good examples of WDP that have mobilized a big amount of people that are placed at the dam construction sites in precarious settlements, where they may stay for several years during the reservoir construction. This demographic pressure may directly modify the local physical and biotical environments, thus producing new epidemiological risks factors ${ }^{36}$. An. darlingi, An. albitarsis s.l, An. aquasalis, An. nuneztovari and An. triannulatus s.l have been encountered in Brazil naturally transmitting human Plasmodium parasites in areas under a WDP influence ${ }^{37,78}$.

In Latin America, most of the man-made lakes have been associated with a worsened health status of the at-risk communities, mainly due to a recrudescence of some vector-borne diseases ${ }^{90}$. The Balbina, Itaipu and Serra da Mesa dams in Brazil are good examples of the effect of dams on malaria. Although malaria does not pose such a major public health problem like in others parts of Africa and Asia, in the Americas WDP may exert a more profound effect on the determinants of the disease ${ }^{49}$.

The construction of man-made lakes is normally associated with a decline of the mosquito diversity, favouring only those species that can adapt to the new artificial environments. In the Balbina dam the opposite effect occurred, with 11 anopheline species reported after five years of the filling of the reservoir compared with only two species found during the pre-intervention surveys. An. darlingi and An. nuneztovari were found naturally infected with Plasmodium parasites $^{65}$. Still in Brazil, An. darling $i$ was also found to be the predominant species in the influence area of the Porteira and Porto Primavera dams and in the area where the future Madeira dam will be constructed ${ }^{7,17,34,88}$.

The Itaipu dam is one of the best documented cases where the combination of demographic, epidemiological and entomological factors brought back malaria transmission in an area where it was under control $^{37,89}$. Before the reservoir construction malaria transmission was almost inexistent in the area. In the 70s a big contingent of people from Paraná (the southern Brazilian State where the dam was planed) moved to other states of the legal Amazon, looking for a better future. Defeated by the hard living conditions of their new settlements, they eventually came back to Paraná, some of them introducing new Plasmodium parasite strains in the area under the influence of the Itaipu dam. An. darlingi populations had been favoured by the new breeding opportunities of the impoundment and this efficient vector entered in contact with the returning infected people, resulting in 3000 malaria cases between 1989 and 1992. An. albitarsis s.l and An. galvaoi were also appointed as vectors with epidemiological relevance in this area ${ }^{22,37}$.

A similar situation occurred in the Serra da Mesa dam in Brazil, where human intrusion, followed by environmental changes that altered vector biology, also resulted in increased malaria incidence. Once more, An. darling $i$ was appointed as the principal factor responsible for sustaining the malaria transmission in the reservoir area. In this case, the importance of An. albitarsis s.l as a vector was again highlighted due to its high capacity of adaptation to human made environments ${ }^{36}$. An. albitarsis s.l densities were also increased when the Taquaraçu and Rosal dams were completed, both in Brazil ${ }^{67,90}$.

\section{IRRIGATION SCHEMES}

Very old observations already associated rice-harvested areas with malaria. For example, in 1489 rice production was outlawed in Spain, while in Portugal, the Czech Republic and North America, paddy fields were thought to be associated with the increase of malaria during the XVII century ${ }^{50,75}$. Overall, few studies that compare malaria incidence before and after an irrigation scheme is implanted have been consistently reported. Paddy fields are usually introduced in soils with a greater capacity to retain water. So, it is probable that communities where irrigations schemes have been established already had a higher transmission levels than control ones, making it more difficult to conduct reliable post-intervention comparisons ${ }^{44}$.

Irrigation systems represent the $75 \%$ of the total rice production and are the most useful approach to allow the culture of this crop in areas of irregular rainfall patterns and arid and semi-arid regions, apart 


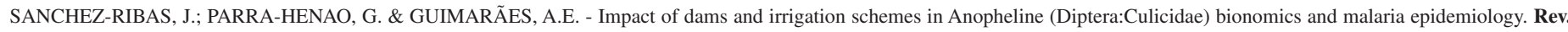
Inst. Med. Trop. Sao Paulo, 54(4): 179-91, 2012.

from increasing the number and the productivity of crop cultures per year ${ }^{50}$. In order to meet the growing food demand, a $70 \%$ increase in global rice production is estimated within the next 25 years, with most of the production expected in developing countries ${ }^{73}$. Nevertheless, rice flooded fields result in habitat simplification, an exacerbated number of potential breeding sites due to a higher availability of water bodies and microclimate modifications. These are factors that may induce the proliferation of certain anopheline species ${ }^{1}$. For example, due to high humidity levels in irrigated fields, the local Egyptian malaria vector, An. pharoensis, lengthened its longevity ${ }^{73}$.

\section{AFRICA}

Only around $8.5 \%$ of African agricultural production is under irrigation systems, but this tendency is expected to increase steadily in the coming years. Almost half of Africa is too dry to rely only in rainfall for agricultural purposes, so irrigation is the best approach to convert arid and semi-arid land extensions in productive areas. There is a clear overlapping distribution between the main malaria vectors and the potential areas for irrigation cultivation ${ }^{44,50}$.

Various reports related irrigated agro-ecosystems with an exacerbated malaria burden, sometimes changing the transmission patterns from seasonal to perennial or increasing the degree of endemicity. In paddy fields of the Rusizi area in Burundi, a sharp increase in P. falciparum malaria cases was related with a higher production of An. arabiensis in the flooded fields ${ }^{10}$. DIUK-WASSER et al. ${ }^{19}$ showed that irrigation schemes also increased the densities of An. gambiae s.s in Mali, mainly during the early crop stages. In this example, the effect of the irrigated crops on malaria was different depending on the dry (increased transmission) or wet season (curtailed transmission). In Sierra Leone, an area under irrigation was occupied by lots of people escaping from other endemic areas under conflict. The introduction of parasites plus the presence of local competent vectors conduced again to a worsened public health situation $^{26}$. Similarly, in rice-growing areas of the Gezira-Managil scheme in Sudan, the combination of increased densities of An. arabiensis and the arrival of people from other neighbouring endemic areas, resulted in an exacerbated malaria burden and the change of the malaria transmission pattern from seasonal to perennial ${ }^{21}$. This phenomenon was also verified in the Manantali dam influence area in $\mathrm{Mali}^{47}$. In areas proximal to an irrigation scheme in Cameroon, high densities of An. arabiensis and An. gambiae s.s accounted for an Entomological Inoculation Rate (EIR) of 0.82 infective bites/person/night. With crop maturation, An. pharoensis became more abundant and was also involved in malaria transmission ${ }^{68}$.

MARRAMA et $a l .{ }^{58}$ conducted a study of the effect of irrigated ricefields in two areas with different epidemiological patterns in Madagascar, one sub-arid region (unstable transmission) and another tropical humid area (stable transmission). In the sub-arid region the EIR was 150 times higher (63 infective bites/person/year mainly due to An. funestus) in areas within the influence of the paddy fields when compared with farther away communities. In addition, the transmission pattern changed from seasonal to perennial, thus converting this area into a stable transmission focus inside an originally unstable transmission area. A similar situation occurred in unstable transmission areas of the Madagascar highlands, where irrigation projects favoured the proliferation of An. funestus, resulting in severe malaria epidemics ${ }^{49}$. In the tropical humid area the transmission was not increased due to paddy fields, and An. mascarensis, which is an endemic species to the island, was appointed as the primary vector ${ }^{58}$.

Contrasting with the previous examples, not always flooded paddy fields have been associated with increased malaria transmission. IJUMBA \& LINDSAY ${ }^{44}$ depicted the situation where a marked increase of anopheline densities due to ricefields did not result in exacerbated malaria incidence. This phenomenon can be explained due to the better economic and social conditions of the communities living near the irrigation schemes, where more reliable health structures, better housing conditions and more resources to be spent in vector control and efficient treatments and preventive measures exist. This was verified in stable transmission areas of paddy fields in the Ivory Coast ${ }^{40}$, Cameroon $^{4}$, and in northern Tanzania ${ }^{45}$. In the last example, although An. arabiensis densities were four times higher in irrigated areas, an EIR between 61 and 68\% lower was observed. The authors surmised that this observation was in part because of the lower preference to take blood from human hosts.

Three factors explained why, in rice irrigated areas in Burkina Faso that recorded four times higher An. gambiae s.l densities, exacerbated malaria transmission was not recorded. Due to very high vector densities, an increased use of bednets reduced the contact rates between settlers and the mosquito fauna. Like in the case of the dams of the Senegal River, increased mosquito densities resulted in decreased survivorship, so the mosquitoes did not live long enough to allow the full parasite development inside them. Thirdly, it was suggested that nulliparous females were more anthropophilic than parous ones ${ }^{10}$. A similar situation happened in the irrigation scheme of Ahero in Kenya and in an irrigated sahelian sub-arid area of Mali, where high mosquito densities were coupled with lower mosquito survival rates and anthropophilia, resulting in lowered sporozoite rates and transmission of malaria ${ }^{20,46}$.

\section{ASIA AND THE PACIFIC}

Several examples presented the negative health effects of irrigation schemes in this region. In Turkey, irrigated crops resulted in an increased population density of the local malaria vector An. sacharovi, which in association with the parasite introduction by workers coming from other endemic areas of the country, provoked in 1977 a severe epidemic of P.vivax with 101,867 recorded cases ${ }^{35}$. A very similar situation occurred in Afghanistan. In this case, An. pulcherrimus and An. hyrcanus were the local species to benefit from irrigated fields. Also, an introduction of parasites by people escaping from endemic conflict-stricken zones played an important role in the subsequent increase in P.vivax transmission ${ }^{23}$.

Several examples of WDP and increased malaria transmission come from India. In the Punjab area, the transmission pattern was switched from seasonal to perennial due to irrigation fields. Higher humidity levels also increased mosquito longevity ${ }^{74}$. In the Asian region of the Thar Desert, An. culicifacies invaded newly implanted paddy fields, and subsequent $P$. falciparum epidemics started to occur in the area. An. stephensi had maintained low transmission levels in this area before irrigation. It was verified that this vector also adapted to spillages from irrigation canals. In another instance, An. culicifacies and An. fluviatilis invaded the irrigation areas along the Narmada river, changing the transmission pattern again from seasonal to perennial and with a malaria incidence 10-15 times higher $^{92}$. Areas irrigated by the Bargi dam showed increased malaria 


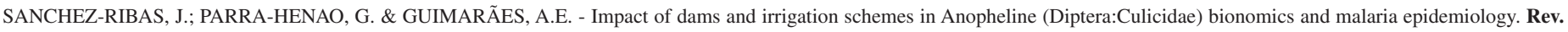
Inst. Med. Trop. Sao Paulo, 54(4): 179-91, 2012.

incidence by four fold, but in this case, An. annularis was the predominant anopheline species ${ }^{81}$. This vector was also important for the occurrence of P.vivax infections in the irrigation scheme of Mahaweli in Sri Lanka. However, this secondary vector was not able to maintain the incidence at the same levels than when An. culicifacies was the main responsible for Plasmodium transmission in the same area during preceding rice developmental stages ${ }^{1,2,66}$.

Irrigated fields promoted the proliferation of anopheline species and increased malaria transmission in other countries of Asia, such as China (An. sinensis), Indonesia (An. aconitus and An. barbitorsis) and Laos PDR (An. nivipes as the suspected vector) ${ }^{52,75}$. In another area of Indonesia, the forest species An. umbrosus, was substituted due to paddy fields implementation by the more efficient vector An. campestris, resulting in local malaria outbreaks ${ }^{96}$.

\section{LATIN AMERICA}

Few studies have recorded the effect of irrigation schemes on malaria in this continent. In Central America, the main malaria vector An. albimanus was favoured by irrigation systems and concomitantly with the arrival of people from endemic areas, the risk for P.vivax infection was triggered. Increased densities of An. albimanus, An. calderoni and An. pseudopunctipennis were recorded in irrigation areas of an arid coastal region of Peru ${ }^{70}$. FORATTINI et al. ${ }^{24,25}$ compiled information on the effect of ricefields on local Anopheles populations in the Vale da Ribeira in southeast Brazil. Their results revealed that An. albitarsis s.l was the species that proliferated more efficiently in these new environments. An. aquasalis was incriminated as a vector in irrigation areas of the British Guyenne $^{31}$.

Colonization schemes such as agricultural settlements in areas of the Amazon frontier, may also jeopardize the health of the local population ${ }^{14}$. For example, in the Jari irrigation scheme of the central Amazon basin, An. darlingi found excellent new breeding sites to prosper and thus, posed an increased risk for malaria transmission in the area ${ }^{54}$. Similarly, in the northern Amazon, BARROS et al. ${ }^{5}$ verified that an agricultural settlement registered much more malaria cases than a neighbouring site without dams being used for crop production.

Anopheline mosquitoes may modify their behaviour to survive. A prime example was found in British Guyenne. In the coastal areas, An. darlingi and malaria were brought under control due to sound control methods. However, expansion of rice cultivation plus the arrival of people from endemic areas to work in the new water projects drew a new epidemiological scenario conducive for malaria transmission. With the reduction of livestock as well, the secondary vector An. aquasalis, which had been up to that moment highly zoophilic, shifted its attention to humans, renewing $P$. vivax transmission ${ }^{31,34}$.

All the studies retrieved for the present review are summarized in Table 1, providing information on the effect on mosquito population dynamics and malaria transmission of each WDP.

\section{CONTROL IN WATER DEVELOPMENT PROJECTS}

In order to select an appropriate location to implement a WDP, research on the following factors is encouraged; i) bionomics of local anopheline species, ii) characteristics of the communities that will be placed under the influence of the WDP, iii) environmental variables that may modulate malaria transmission and iv) the capacity of the local health system to respond efficiently to risk situations. This knowledge would also allow control programmes to forecast the negative effects on health of that project in that specific setting and to prepare adequate palliative measures to be implemented ${ }^{8}$. For example, different social groups such as dam workers, dislocated people or traditional tribes may present different susceptibility to health hazards that need to be considered when planning an integrated control program ${ }^{70,83}$. To tackle the negative health outcomes, several strategies of environmental management, biological and chemical control methods and population education approaches may be considered for controlling malaria in WDP.

Insecticide resistance of malaria vectors due to the massive use of chemical compounds in agriculture and public health can hinder control programmes. A prime example of insecticidal resistance due only to agricultural applications was found in some An. albimanus populations of El Salvador ${ }^{27}$. This was confirmed because resistance levels were higher in mosquito populations close to the paddy fields (space correlation), also higher resistance levels were observed during the spraying periods of ricefields (time correlation) and because the agricultural insecticides were less efficient to control Anopheles populations than in previous years ${ }^{27,57}$. In Sri Lanka, resistance due to agricultural pesticides was observed also in An. nigerrimus populations. However, An. culicifacies B developed resistance due to public health campaigns in the same country. This was explained for the different vector ecology and exposure to the different insecticidal compounds. An. culicifacies B rest mainly indoors entering in contact with the insecticides used for Indoor Residual Spraying (IRS), while An. nigerrimus rest principally outdoors and their larvae are largely found in ricefields were the pesticides for agriculture are applied, encountering also resistance in the immature stages ${ }^{39,57}$.

Impregnated bednets have been proven a very useful tool for reducing human-vector contact rate, thus reducing considerably malaria transmission in many areas and settings ${ }^{69}$. In areas under the influence of two dams in the Senegal River, a reduction of $90 \%$ of malaria prevalence was observed in treated communities with impregnated bednets. Their use also proved efficient in the control of infection in the Tigray region of Ethiopia ${ }^{13,29}$. Conversely, bednets were not successful for controlling malaria in the proximities of the Bargi dam in India. This area is inhabited by ancestral tribes with specific socio-cultural characteristics which impeded the proper implantation of the bednets ${ }^{82}$. Large number of mosquitoes produced in flooded fields may represent an intolerable biting rate for irrigation communities, so many households will start to use bednets in a higher rate than neighbouring non-irrigated areas. This situation has been reported in irrigated villages in The Gambia, Cameroon and Burkina Faso. High bednet coverage may explain to some extent why malaria incidence is kept to moderate levels in such irrigated villages with elevated mosquito densities ${ }^{44}$.

Alternative methods to mitigate the malaria burden are IRS and the use of impregnated curtains in windows and repellents. At the Uttaranchal dam in India, a better socioeconomic status and knowledge of the risk factors for malaria of the settlers close to the project, plus sound vector control measures such as IRS, abolished the disease transmission in at risk communities $^{49}$. In Thailand, sound integrated control measures averted 


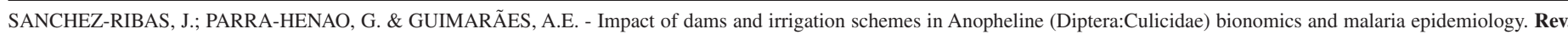
Inst. Med. Trop. Sao Paulo, 54(4): 179-91, 2012.

Table 1

Summary of studies on the impact of water development projects (WDP) on anopheline bionomics and malaria transmission

\begin{tabular}{|c|c|c|c|c|}
\hline Continent/country & Type of WDP & Main malaria vectors & $\begin{array}{c}\text { Effect on anopheline } \\
\text { bionomics * }\end{array}$ & Effect on malaria transmission $* *$ \\
\hline \multicolumn{5}{|l|}{ África } \\
\hline Burkina Faso & Irrigation scheme & An. gambiae s.l & ID & RT (high use of bednets) \\
\hline Burundi & Rusizi ricefields & An. arabiensis & ID & IT of $P$. falciparum \\
\hline Cameroon & Logone ricefields & $\begin{array}{l}\text { An. gambiae s.s, } \\
\text { An. arabiensis }\end{array}$ & ID & IT \\
\hline \multirow[t]{3}{*}{ Ethiopia } & Tigray micro-dams & An. arabiensis & ID & IT \\
\hline & Gilgel-Gibe dam & An. gambiae s.l & ID & IT of $P$. vivax \\
\hline & Koka dam & $\begin{array}{l}\text { An. pharoensis, } \\
\text { An. arabiensis, An. funestus }\end{array}$ & ID & IT \\
\hline Gambia & Irrigation scheme & $\begin{array}{l}\text { An. gambiae s.s, } \\
\text { An. arabiensis }\end{array}$ & ID & NT in the dry season \\
\hline Ivory Coast & Irrigation scheme & An. gambiae s.l & ID & NT (better socio-economic conditions) \\
\hline \multirow[t]{2}{*}{ Kenya } & Mwea ricefields & $\begin{array}{l}\text { An. gambiae s.l, } \\
\text { An. pharoensis }\end{array}$ & ID & IT \\
\hline & Ahero ricefields & An. arabiensis, An. funestus & ID & NT (Effective IRS) \\
\hline \multirow[t]{2}{*}{ Madagascar } & Highlands ricefields & An. funestus & ID & IT (P.falciparum epidemics) \\
\hline & Southern ricefields & $\begin{array}{l}\text { An. funestus, } \\
\text { An. mascarensis }\end{array}$ & ID & IT in arid and NT in humid areas \\
\hline Mali & Sahelian ricefields & An. gambiae s.s & ID & $\begin{array}{l}\text { IT in dry season and RT in rainy } \\
\text { season }\end{array}$ \\
\hline \multirow[t]{2}{*}{ Senegal } & Diama dam & $\begin{array}{l}\text { An. pharoensis, } \\
\text { An. gambiae s.l, } \\
\text { An. funestus }\end{array}$ & $\begin{array}{l}\text { ID of An. pharoensis } \\
\text { and An. funestus }\end{array}$ & NT (high coverage of bednets) \\
\hline & Irrigation scheme & An. pharoensis & ID & NT \\
\hline Sudan & Gezira ricefields & An. arabiensis & ID & $\begin{array}{l}\text { IT at the beginning, RT after efficient } \\
\text { malaria control }\end{array}$ \\
\hline Tanzania & Irrigation scheme & An. arabiensis & ID & $\begin{array}{l}\text { RT (bednets, prompt and efficient } \\
\text { treatment, screened windows) }\end{array}$ \\
\hline \multicolumn{5}{|l|}{ Asia and the Pacific } \\
\hline Afghanistan & Irrigation scheme & $\begin{array}{l}\text { An. pulcherrimus, } \\
\text { An. hyrcanus }\end{array}$ & ID & IT \\
\hline Bangladesh & Lowland dams & An. philippinensis & $\mathrm{RD}$ & RT \\
\hline China & Irrigation scheme & An. sinensis & ID & IT \\
\hline \multirow[t]{5}{*}{ India } & Uttaranchal dam & $\begin{array}{l}\text { An. culicifacies, } \\
\text { An. fluviatilis }\end{array}$ & $\mathrm{RD}$ & $\begin{array}{l}\text { RT (efficient control and better socio- } \\
\text { economic conditions) }\end{array}$ \\
\hline & Bargi dam & $\begin{array}{l}\text { An. culicifacies, } \\
\text { An. fluviatilis }\end{array}$ & $\begin{array}{l}\text { RD An. culicifacies and } \\
\text { ID of An. fluviatilis }\end{array}$ & $\begin{array}{l}\text { IT and increased proportion of } \\
\text { P.falciparum infections }\end{array}$ \\
\hline & Micro-dams & $\begin{array}{l}\text { An. fluviatilis, } \\
\text { An. culicifacies }\end{array}$ & $\mathrm{RD}$ & $\mathrm{RT}$ \\
\hline & Thar Desert ricefields & $\begin{array}{l}\text { An. culicifacies, } \\
\text { An. stephensi }\end{array}$ & ID & IT and predominance of $P$. falciparum \\
\hline & Narmada ricefields & $\begin{array}{l}\text { An. culicifacies, } \\
\text { An. fluviatilis }\end{array}$ & ID & IT \\
\hline \multirow[t]{2}{*}{ Indonesia } & Coastal ricefields & An. campestris & ID & IT \\
\hline & Irrigation scheme & $\begin{array}{l}\text { An. barbitorsis, } \\
\text { An. aconitus }\end{array}$ & ID & IT \\
\hline Laos PDR & Irrigation scheme & An. nivipes & ID & IT \\
\hline
\end{tabular}




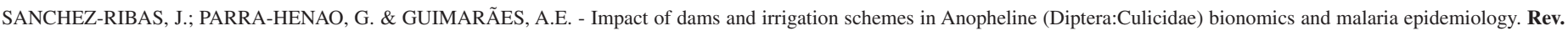
Inst. Med. Trop. Sao Paulo, 54(4): 179-91, 2012.

Table 1

Summary of studies on the impact of water development projects (WDP) on anopheline bionomics and malaria transmission.(cont.)

\begin{tabular}{|c|c|c|c|c|}
\hline Continent/country & Type of WDP & Main malaria vectors & $\begin{array}{c}\text { Effect on anopheline } \\
\text { bionomics } *\end{array}$ & Effect on malaria transmission $* *$ \\
\hline \multicolumn{5}{|l|}{ Asia and the Pacific } \\
\hline Nepal & Irrigation scheme & An. culicifacies A & ID & IT \\
\hline Sri Lanka & Mahaweli ricefields & $\begin{array}{l}\text { An. annularis, An. subpictus } \\
\text { An. culicifacies B }\end{array}$ & $\begin{array}{l}\text { ID An. annularis and } \\
\text { RD An. culicifacies B }\end{array}$ & $\begin{array}{l}\text { IT at the beginning, RT (IRS and } \\
\text { prompt and effective treatment) }\end{array}$ \\
\hline Thailand & Srinagarind dam & $\begin{array}{l}\text { An. minimus, } \\
\text { An. balabacensis, } \\
\text { An. maculatus }\end{array}$ & ID & IT \\
\hline Turkey & Irrigation scheme & An. sacharovi & ID & IT, $P$. vivax epidemics \\
\hline \multicolumn{5}{|l|}{ Latin America } \\
\hline \multirow[t]{13}{*}{ Brazil } & Balbina dam & An. nuneztovari & ID & NT (efficient malaria control) \\
\hline & Samuel dam & Anopheles sp & ID & IT \\
\hline & Tucurui dam & $\begin{array}{l}\text { An. nuneztovari, } \\
\text { An. braziliensis }\end{array}$ & ID & IT \\
\hline & Itaipu dam & $\begin{array}{l}\text { An. darlingi, } \\
\text { An. albitarsis s.l, } \\
\text { An. galvaoi }\end{array}$ & ID & IT \\
\hline & Serra da Mesa dam & An. darlingi & ID & IT \\
\hline & Taquaruçu dam & $\begin{array}{l}\text { An. albitarsis s.l, } \\
\text { An. darlingi }\end{array}$ & ID & No malaria transmission \\
\hline & Porto Primavera dam & An. darlingi & ID & No malaria transmission \\
\hline & Rosal dam & An. albitarsis & ID & No malaria transmission \\
\hline & Igarapava dam & $\begin{array}{l}\text { An. darlingi, } \\
\text { An. albitarsis s.l }\end{array}$ & ID & No malaria transmission \\
\hline & Peixe Angical dam & $\begin{array}{l}\text { An. darlingi, } \\
\text { An. albitarsis s.l, } \\
\text { An. triannulatus }\end{array}$ & ID & No malaria transmission \\
\hline & Jari irrigation scheme & An. darlingi & ID & IT \\
\hline & $\begin{array}{l}\text { North Amazon agricul- } \\
\text { tural settlement }\end{array}$ & An. darlingi & ID & IT \\
\hline & Southeast ricefields & An. albitarsis s.l & ID & No malaria transmission \\
\hline British Guyenne & Irrigation scheme & An. aquasalis & $\mathrm{BC}$ & IT. $P$. vivax epidemic \\
\hline Central America & Irrigation scheme & An. albimanus & ID & IT \\
\hline Peru & Irrigation scheme & $\begin{array}{l}\text { An. albimanus, } \\
\text { An. pseudopunctipennis }\end{array}$ & ID & IT \\
\hline Suriname & Brokopondo dam & $\begin{array}{l}\text { An. darlingi } \\
\text { An. nuneztovari }\end{array}$ & ID of An. nuneztovari & \\
\hline
\end{tabular}

*ID - Increased Densities, RD - Reduced Densities , BC - Behaviour Change. ** IT - Increased Transmission, RT - Reduced Transmission, NT - No Transmission modification

the increase on malaria incidence in adjacent areas of the Ubolratana $\mathrm{dam}^{85}$. Another example in this region comes from Laos PDR, were epidemiological surveys demonstrated that control measures efficiently reduced the endemicity at a very low degree in areas close to an artificial lake in the Keoudum district ${ }^{30}$. It is important to bear in mind that pressure due to control measures may affect the behaviour of malaria vectors. This phenomenon was observed at the Tucurui dam in Brazil, where the local An. darlingi population shifted to a more exophilic behaviour due to the pressure of control measures such as IRS and impregnated curtains, coupled with a change in human behaviour ${ }^{87}$.
To overcome insecticide resistance problems, environmental management and biological agents for malaria control have been highlighted. It is important to know the bionomics of all potential malaria vectors of a specific area when applying environmental management strategies, as a specific intervention may deter a species to colonize the site but may benefit the adaptation of another local species with a different vector capacity ${ }^{93}$. Environmental manipulation consists in actions that produce temporary conditions that are unfavourable for mosquito proliferation in WDP. All these control methods may be used along the different parts of a WDP, from the artificial lake that stores the 


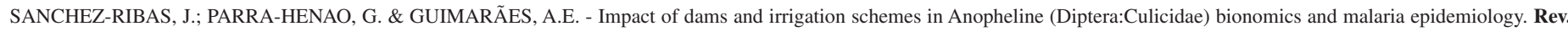
Inst. Med. Trop. Sao Paulo, 54(4): 179-91, 2012.

water for its distribution and energy production to the drainage systems, passing through the distribution canals and paddy fields ${ }^{97,98}$. For example, if irrigation canals are lined in order to avoid the formation of standing water bodies, with proper edge maintenance and vegetation removal, a reduction of potential breeding sites may be achieved ${ }^{99}$. This was observed between well planned and unplanned ricefields in the irrigation scheme of Mwea in Kenya. Larval densities were higher in the unplanned rice growing villages as their canals and flooded fields were not properly drained, providing more opportunities for Anopheles to breed ${ }^{62}$.

An easy and effective strategy to reduce negative health impacts is to establish these WDP far enough from the communities, so that they are out of the flight range of the local anopheline species ${ }^{29}$. The filling of a reservoir will cover several isolated natural breeding sites in a determined area, although an extensive new shoreline may be used for the Anophelinae to breed. So, a more extensive area that can become a potential breeding site will be defined, but this area would be easier to identify and control than the sparse natural water bodies ${ }^{98}$. In some South American ecosystems, like the "cerrado" and "caatinga", the implementation of irrigated schemes may reduce the sources of breeding, decreasing in turn the anopheline densities and malaria transmission ${ }^{70}$. Community participation may enhance control programs in WDP, as was proved in the Tigray area of Ethiopia, where local communities and health workers were implicated in the filling or drainage of potential breeding sites ${ }^{102}$.

For efficient malaria control in man-made lakes, another strategy for mosquito population abatement is to fluctuate periodically the lake water levels and hence alter the flight range of local Anopheles. For example, during the dry season, reservoir capacity may be lowered considerably and the area under the flight range of mosquitoes may be considerably curtailed, placing some communities at less risk of acquiring the disease ${ }^{49}$. Nevertheless, this control strategy must be carefully planned, as it was observed that, when the Samuel dam in Brazil naturally reduced its water levels during the dry season, malaria incidence and Anopheles populations were exacerbated due to the exposure of new areas of land with stagnant water $^{79}$. The efficiency of fluctuating reservoir water levels also depends on the correct maintenance of the banks, mainly reducing the amount of associated vegetation that may facilitate some mosquitoes to breed. One of the first examples of the success of fluctuating water levels and the removal of vegetation from the lake edge for anopheline control comes from the dams at the Hales Bar and Falling Water rivers in the U.S.A., where An. quadrimaculatus was responsible for severe epidemics ${ }^{95}$. GUIMARÃES et al..$^{36}$ conducted an analysis between the lake's shoreline characteristics and water level fluctuations and variations in mosquito populations in the Serra da Mesa Brazilian reservoir. Keeping 10 meters above the shoreline free of vegetation was argued to be a key factor to avoid the proliferation of Anopheles sp. during the first stage of the WDP, and especially for An. darlingi that cannot breed in totally exposed sites. Anophelinae densities were highly correlated with the fluctuation of dam water level, increasing when water contacted the surrounding vegetation. This phenomenon was also reported from the Peixe Angical dam in Brazil, where the highest number of An. darlingi were recorded when the reservoir was being filled, as this process was accompanied by increased decomposition of vegetation along the banks and greater shading of the reservoir margins ${ }^{78}$. Variations in reservoir water level also impeded the maintenance of proper breeding sites of An.darlingi at the Lages dam in Brazil, thereby substantially curtailing human exposure ${ }^{41}$.
Periodic discharges from the reservoir may reduce breeding in water distribution channels and other areas downstream ${ }^{98,99}$. This last strategy probed to be useful to maintain at low levels An. culicifacies populations in downstream areas of a WDP in Sri Lanka ${ }^{53}$.

Intermittent irrigation is a classic and very efficient method to control mosquito populations in paddy fields, consisting of repetitive dry stages of the crops, not allowing the water to be on the cultures for more time than the larval development of the anophelines. This approach may also increase crop productivity. Depending mainly on temperature (larvae development is faster in the tropics) and also in each specie's biology, the time estimated from when the egg is laid until the complete development of the adult mosquito may be around 18 days ${ }^{50}$. Another factor to consider is the time that anopheline eggs may stay viable in the dried fields. For example, eggs of An. sinensis may resist for three days without water in soils with a minimum of $90 \%$ of humidity. Intermittently irrigated ricefields may be implemented in areas with enough water availability and without high rainfall patterns ${ }^{59}$. Positive experiences reducing malaria incidence due to intermittent irrigation are reported from the Senjayakollai area in India (reduction of parasite rates from $42 \%$ to $0 \%$ ) and in China, where malaria prevalence declined due to a fall of $84-86 \%$ of the An. sinensis larvae populations. Intermittent irrigation and insecticides may reduce the population of mosquito predators present in the paddy fields, which in some cases may exert high pressure to maintain mosquito densities at low levels $\mathrm{s}^{50,72}$.

Some study cases have shown that very high mosquito densities may reduce the longevity of the vector, thus mitigating malaria transmission. Based on this observation, malaria transmission could be controlled by synchronizing all the paddy fields of an area in order that only a small proportion or most of them are in the same developmental stage. During rainy season, an increased mosquito production of paddy fields may produce such high mosquito densities that anopheline longevity may be reduced. Also, it is easier to implement focalised control measures if only some ricefields are operated around determined irrigation communities ${ }^{19}$.

There are many examples of the use of biological methods to abate Anopheles populations in ricefields. The main strategies are using fish as predators, microbial agents such as Bacillus thuringiensis var. israelensis and B. sphaericus and nematodes that can parasite mosquitoes such as Romanomermis culicivorax ${ }^{54}$. For example, the use in China of larvivorious fish was seen to be useful to reduce mosquito populations in paddy fields, helped in the fertilization of the crops and also provided with extra $50 \mathrm{~kg}$ of fish for each 15 hectares of cultivated rice to the local population ${ }^{98}$.

Geographic Information Systems (GIS) and spatial analysis have been increasingly used in recent years for the study and control of vector-borne disease ${ }^{64}$. This tool can assist us in the prediction of epidemiological risk situations and they have proved to be of great applicability in areas under the influence of a WDP. A first example comes from Mali, where a GIS was used to evaluate if paddy fields mapped with remote systems, could explain the variations of mosquito densities among some communities. The authors highlighted that the water management of irrigated fields was the most influential factor that modulated the mosquito population dynamics ${ }^{19}$.

LAUTZE et al. ${ }^{55}$ concluded using a GIS that the distance of the communities to the Koka reservoir in Ethiopia was one of the variables 


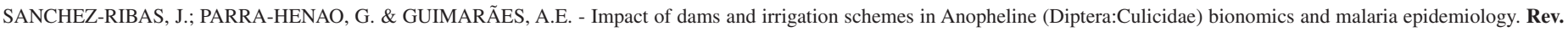
Inst. Med. Trop. Sao Paulo, 54(4): 179-91, 2012.

more highly correlated with malaria incidence. They verified that communities placed in a distance of 0-3 km, 3-6 km and 6-9 km from the lake shoreline presented infection rates per 1000 people/month of $6.74,4.60$ and 2.91 respectively. This difference in malaria exposure is related to the decreasing gradation of vector densities that is normally established from the WDP margins. For example, 17 bites/person/night by An. gambiae s.l were recorded in the margins of an irrigated scheme in Senegal. This index dropped to one bite/person/night in areas located at $5 \mathrm{~km}^{20}$.

In the Amazonian region, VITTOR et al. ${ }^{94}$ applied GIS to analyze the impact of different land use in the Peruvian Amazon and to predict variations in An. darlingi distributions and densities. They concluded that the EIR was gradually increased in areas with a higher proportion of grass/crop land. Another example is provided by ZEILHOFER et al. ${ }^{103}$ who used GIS at the Manso dam, Brazil, to model the suitable breeding site habitats for An. darlingi. Environmental and climatic factors such as temperature, humidity, rainfall, distance to potential breeding sites, topography and lake border vegetation cover, were correlated with the spatial and temporal distribution of this vector. This analysis allowed the generation of a detailed map of the dam area, highlighting the most favourable spots for An. darlingi to breed.

\section{DISCUSSION}

It is estimated that by year 2025 , a total of 9,4 billion people should have their food and energetic demands covered. As a result it is expected that irrigation schemes and dams will be extensively expanded mainly in the tropics. For this reason, if sound prevention measures are not properly implemented, a global health deterioration related to these WDP may be anticipated ${ }^{50}$.

We have reviewed several studies that assessed the effect of dams and irrigation on Anopheles bionomics and malaria epidemiology, defining diverse situations, such as increased vector densities accompanied by increased, decreased or no changes in malaria transmission, decreased vector densities, ecological succession of mosquito fauna and vector behaviour modifications.

When population movements introduce new Plasmodium parasites in free or under control malaria areas, several factors such as human population densities and acquired immunity levels, climate, available prevention and control measures and very importantly, the presence of an efficient vector in enough numbers, will determine if a new transmission focus will be established ${ }^{35}$. The establishment of a new malaria foci has been well documented in areas under WDP influence of Africa (i.e: Gilgel-Gibe dam in Ethiopia and several sub-Saharan irrigation schemes), Asia and the Pacific (i.e: Bargi dam and Thar Desert ricefields in India and Srinagaring dam in Thailand) and the Americas (i.e: Serra da Mesa and Itaipu dams in Brazil) $)^{22,36,37,40,88,99}$.

Each anopheline species has its own optimal breeding requirements, such as sun level exposure, water turbidity and temperature, current, presence of associated vegetation, $\mathrm{pH}$ and organic matter concentration. For this reason, not all WDP will provide optimum breeding grounds for the local malaria vectors ${ }^{49}$. Usually species with preference for exposed breeding sites thrive more efficiently in man-made lakes. For example, An. arabiensis has a preference for open sunlit breeding sites with few associated vegetation and a certain degree of turbidity ${ }^{35}$. This species thrived in some WDP that presented such conditions, like the Koka dam and the micro-dams of the Tigray region, both in Ethiopia. An. nuneztovari has also preference for natural sun exposed breeding sites, such as pools, slow flow streams, lakes and animal footprints. This vector has been found breeding efficiently in many man-made lakes such as de Balbina and Tucurui dams in Brazil and the Brokopondo dam in Suriname, inclusive displacing other anopheline species and developing resistance to insecticides ${ }^{87,88}$. At the Tucurui dam, an increase from 25.6 to 53.3 mosquito bites/person/hour were registered and the biting activity peak of the anophelines was advanced to 18:00 due to the enormous proliferation of Mansonia sp populations, also well adapted to the new environmental conditions ${ }^{70,88}$. Moreover, proliferation of the less sun-loving An. darlingi in dams is observed when project margins are associated with vegetation that creates appropriate breeding conditions for this species. This has been reported from the Itaipu, Serra da Mesa and Manso dams in Brazil. From South America, also An. albitarsis s.l has been several times associated with man-made lakes or irrigation projects. An. culicifacies, a primary malaria vector in most of the Asian continent, shows low adaptability to irrigated areas. This vector tends to disappear from rice cultivations when the crops reach $76 \mathrm{~cm}$ but it can be abundant in water distribution canals and spillages of the $\mathrm{WDP}^{75}$. An. culicifacies is a complex of species. In Sri Lanka An. culicifacies $\mathrm{B}$ is predominant and it has few adaptability to flooded ricefields ${ }^{51}$. In contrast, An. culicifacies A has showed better potential to colonize this environment in Nepal, increasing malaria transmission ${ }^{100}$. Other Asiatic primary malaria vectors such as An. fluviatilis, An. stephensi, An. minimus and $A n$. dirus are not good colonizers of paddy fields. On the other hand, secondary vectors with more limited potential for malaria transmission such as An. annularis, An. varuna and An. jeyporiensis are well adapted to these artificial settings ${ }^{75}$.

The majority of Anopheles species have a great potential to colonize and exploit new water bodies. The flight range of most of anopheline mosquitoes between breeding sites and blood meal points varies between 1.5 and $2 \mathrm{~km}$. However, sporadic migratory movements assisted by winds may extend this flight range up to $50 \mathrm{~km}^{99}$. Other studies proved that An. gambiae can fly longer distance from irrigated fields during the dry season ${ }^{19}$. Due to this high adaptability and mobility capabilities, if a malaria vector is present in an area of a WDP implantation, it may eventually colonize it. There are diverse examples of colonization of new areas by different anopheline species. An. braziliensis colonized the Tucurui dam area in Brazil five years after the filling of the reservoir and An. culicifacies, a vector absent in the area of the Thar Desert in India, used the new implanted irrigation schemes as new breeding sites to colonize the region ${ }^{92}$. As a result of WDP in Egypt, An. gambiae invaded the new areas from Sudan, provoking severe epidemics with almost 130,000 deaths between 1942 and $1943^{43}$.

When determining if anopheline species will successfully adapt and proliferate in WDP, climatic and other biotic and abiotic factors may play an important role. For example, in the Amazon exists three types of rivers (white, black and clear water rivers) which differ in parameters such as the $\mathrm{pH}$, concentration of organic matter, sediments and associated vegetation. The differential effect on the mosquito populations of the different dams in the Amazon will be determined to some extent for the type of river dammed. For instance, macrofits proliferation (such as Pistia stratiotes and Echhornia crassipes) is well sustained in white water rivers 
SANCHEZ-RIBAS, J.; PARRA-HENAO, G. \& GUIMARÃES, A.E. - Impact of dams and irrigation schemes in Anopheline (Diptera:Culicidae) bionomics and malaria epidemiology. Rev. Inst. Med. Trop. Sao Paulo, 54(4): 179-91, 2012.

(Tucurui dam) and not in black water rivers. These macrofits have been associated with an increased production of the main malaria vector of the Amazon, An. darlingi ${ }^{65}$.

Temperature and rainfall are the two main climatic factors that have influence on malaria transmission. The later determines the number of potential breeding sites and hence, vector densities, while the former ascertains the duration of the larval development and the sporogonic cycle inside the mosquito ${ }^{61}$. GUIMARÃES et al. ${ }^{37}$ pointed out that in the area under the influence of the Itaipu dam, rainfall did not pose a direct influence on mosquito densities, as the reservoir experienced few water level fluctuations, thus remaining a stable breeding site independent from the rain patterns. In contrast, another report from the Peixe Angical dam in Brazil, demonstrated that climatic factors played an important role, as greater rainfall influenced negatively on the abundance of An. albitarsis s.l and An. triannulatus s.l. In addition, higher temperatures were related with increased numbers of An. albitarsis s.l at the dam site ${ }^{78}$. Another example of the key role of climatic factors in man-made environments is found in a sahelian area of the Gambia, where malaria transmission is intense during the rainy season and very limited during the drier months. The introduction of irrigated schemes in this setting offered new potential breeding sites for local malaria vectors. This resulted in another peak of high mosquito densities during the dry months but, surprisingly, without an increase in malaria incidence. The extreme temperatures of $42.7^{\circ} \mathrm{C}$ in the shadow and the very low relative humidity affected the adult mosquito survival rates. In addition, there are some evidences that the extreme temperatures may be also lethal for the Plasmodium parasites, impairing also their development inside the Anopheles. This was a case of "Anophelism without malaria"56.

Almost 25\% of the known species of Anopheles that can transmit malaria can thrive in ricefields. Different anopheline species will predominate in different rice crop stages and the mosquito densities are lower when the crops are very tall as the mosquito females find more difficult to reach the water of the paddy fields to lay their eggs ${ }^{100}$. Other factors that may influence mosquito productivity are water depth, duration of flooded periods, growing rate of the crops and the extension area under cultivation ${ }^{50}$.

This succession of Anopheles species during the different crop developmental stages has been well documented. For example, in Africa, An. gambiae s.s and An. arabiensis are more abundant during the early crop stages as they prefer to breed in sun exposed water bodies. An. funestus can be found in higher abundances during later crop stages, as it presents preference for shaded or semi-shaded breeding sites ${ }^{73}$. In other continents, this alternation on anopheline species also occurs. Sun-loving species such as An. albimanus (America), An. fluviatilis and An. culicifacies (Asia) are considered pioneer species in the colonizing of paddy fields, while species that prefer less exposed breeding sites are An. punctimacula (America) and An. umbrosus, An. hyrcanus and An. leucosphyrus (Asia) ${ }^{73}$. This succession of species was also observed in some dams of the Senegal River where An. gambiae s.s and An. arabiensis were the most abundant species before the dam construction, but An. pharoensis became the predominant species when the project was completed, accounting for most of the new malaria infections. The Diama dam also provoked an interruption of the flux of the sea salt upstream the Senegal River, allowing the colonization of the area by An. funestus ${ }^{18,80}$. This ecological succession of species in WDP has important epidemiological significance, as each species has its own vector capacity.

From all cited above, it is important to evaluate the potential health hazards following a holistic and multidisciplinary approach during the design, construction and operation of WDP. Effective control methods have been proved effective in such settings. Active case detection and prompt and effective treatment of infected individuals coming to WDP areas, good maintenance of lake margins coupled with sound water level management, and classic vector control methods such as IRS, the use of impregnated bednets and larval control would be encouraged to tackle malaria in these scenarios. It would be advised to conduct additional site-specific studies in endemic areas (if possible collecting pre- and postintervention data and using consistently, informative parameters such as the EIR) under the direct effect of dams and irrigation schemes, in order to increase our knowledge on this topic and improve our approaches to minimize the negative health effects of these human interventions. We also consider GIS technologies a tool with a high potential to assist on the study and control of malaria in such scenarios, and its use should be further explored.

\section{RESUMO}

\section{Impacto de hidrelétricas e campos de irrigação na bionomia dos anofelinos (Diptera:Culicidae) e na epidemiologia da malária}

Intervenções humanas como projetos de irrigação e usinas hidrelétricas, tem se transformado em graves problemas de saúde em muitos países, especialmente naqueles localizados nos trópicos. No presente artigo discutimos os efeitos que essas intervenções causam a dinâmica populacional dos anofelinos e nos padrões de transmissão de malaria. Foram revisados estudos feitos nas três principais regiões geográficas dos trópicos e sub-trópicos (África, Ásia e o Pacífico e Américas). Constatamos que os padrões da transmissão da malária antes da introdução dos empreendimentos, as medidas de controle, os movimentos demográficos, os padrões comportamentais das comunidades humanas e a bionomia dos anofelinos locais determinarão se o estabelecimento de campos de irrigação e/ou usinas hidrelétricas podem influenciar negativamente na saúde das pessoas. São apresentados exemplos de medidas de controle bem sucedidas nesses cenários. A utilização de Sistemas de Informação Geográfico tem sido destacada como uma importante ferramenta para subsidiar o estudo e controle da malária em áreas sob impacto ambiental.

\section{REFERENCES}

1. Amerasinghe FP, Ariyasena TG. Larval survey of surface water-breeding mosquitoes during irrigation development in the Mahaweli Project, Sri Lanka. J Med Entomol. 1990;27:789-802.

2. Amerasinghe FP, Indrajith NG. Postirrigation breeding patterns of surface water mosquitoes in the Mahaweli Project, Sri Lanka, and comparisons with preceding developmental phases. J Med Entomol. 1994;31:516-23.

3. Atangana S, Foumbi J, Charlois M, Ambroise-Thomas P, Ripert C. Étude épidémiologique de l'onchocercose et du paludisme dans la région du lac de retenue de BamendjinCameroun. Faune malacologique locale et possibilités d'implantation des bilharzioses. Med Trop (Mars). 1979;39:537-43. 
4. Audibert M, Josseran R, Josse R, Adjidji A. Irrigation, schistosomiasis, and malaria in the Logone Valley, Cameroon. Am J Trop Med Hyg. 1990;42:550-60.

5. Barros FS, Honório NA, Arruda ME. Temporal and spatial distribution of malaria within an agricultural settlement of the Brazilian Amazon. J Vector Ecol. 2011;36:159-69.

6. Baudon D, Robert V, Darriet F, Huerre M. Impact de la construction d'un barrage avec retenue d'eau sur la transmission du paludisme. Enquête paludologique menée dans le sud-est de la Mauritanie. Bull Soc Pathol Exot Filiales. 1986;79:123-9.

7. Bicudo M, Gomez A. Culicidae (Diptera) em área sob influência de construção de represa no Estado de São Paulo. Rev Saúde Pública. 2007;41:284-9.

8. Birley M. World Health Organization. Community Water Supply and Sanitation Unit WHO/FAO/UNEP/UNCHS Panel of Experts on Environmental Management for Vector Control. Guidelines for forecasting the vector-borne disease implications of water resources development. $2^{\text {nd }}$ ed. (PEEM Guideline Series 2). Geneva: World Health Organization; 1991. (WHO/CWS/91.3).

9. Birley MH. An historical review of malaria, kala-azar and filariasis in Bangladesh in relation to the Flood Action Plan. Ann Trop Med Parasitol. 1993;87:319-34.

10. Boudin C, Robert V, Carnevale P, Ambroise-Thomas P. Epidemiology of Plasmodium falciparum in a rice field and a savanna area in Burkina Faso. Comparative study on the acquired immunoprotection in native populations. Acta Trop. 1992;51:103-11.

11. Breman JG. The ears of the hippopotamus: manifestations, determinants, and estimates of the malaria burden. Am J Trop Med Hyg. 2001;64(1-2 Suppl):1-11.

12. Bunnag T, Sornmani S, Pinithpongse S, Harinasuta C. Surveillance of water-borne parasitic infections and studies on the impact of ecological changes on vector mosquitoes of malaria after dam construction. Southeast Asian J Trop Med Public Health. 1979; 10:656-60.

13. Carrara GC, Petrarca V, Niang M, Coluzzi M. Anopheles pharoensis and transmission of Plasmodium falciparum in the Senegal River delta, West Africa. Med Vet Entomol. 1990;4:421-4.

14. Castro MC, Monte-Mór RL, Sawyer DO, Singer BH. Malaria risk on the Amazon frontier. Proc Natl Acad Sci USA. 2006;103;2452-7.

15. Centers for Disease Control and Prevention [Malaria facts]. Atlanta, USA. [cited 2012 January 2]. Available from: http://www.cdc.gov/malaria/about/facts.html

16. Coura JR, Suárez-Mutis M, Ladeia-Andrade S. A new challenge for malaria control in Brazil: asymptomatic Plasmodium infection: a review. Mem Inst Oswaldo Cruz. 2006;101:229-37.

17. Cruz RM, Gil LH, de Almeida e Silva A, da Silva Araújo M, Katsuragawa TH. Mosquito abundance and behavior in the influence area of the hydroelectric complex on the Madeira River, Western Amazon, Brazil. Trans R Soc Trop Med Hyg. 2009;103:11746.

18. Dia I, Konate L, Samb B, Sarr JB, Diop A, Rogerie F, et al. Bionomics of malaria vectors and relationship with malaria transmission and epidemiology in three physiographic zones in the Senegal River Basin. Acta Trop. 2008;105:145-53.

19. Diuk-Wasser M, Touré MB, Dolo G, Bagayoko M, Sogoba N, Sissoko I, et al. Effect of rice cultivation patterns on malaria vector abundance in rice-growing villages in Mali. Am J Trop Med Hyg. 2007;76:869-74.

20. Dolo G, Briët O, Dao A, Traoré SF, Bouaré M, Sogoba N, et al. Malaria transmission in relation to rice cultivation in the irrigated Sahel of Mali. Acta Trop. 2004;89:147-59.

21. el Gaddal AA, Haridi AA, Hassan FT, Hussein H. Malaria control in the Gezira-Managil Irrigated Scheme of the Sudan. J Trop Med Hyg. 1985;88:153-9.
22. Falavigna-Guilherme A, Silva AM, Guilherme EV, Morais DL. Retrospective study of malaria prevalence and Anopheles genus in the area of influence of the Binational Itaipu Reservoir. Rev Inst Med Trop Sao Paulo. 2005;47:81-6.

23. Faulde MK, Hoffmann R, Fazilat KM, Hoerauf A. Malaria reemergence in northern Afghanistan. Emerg Infect Dis. 2007;13:1402-4.

24. Forattini O, Kakitani I, Massad E, Marucci D. Studies on mosquitoes (Diptera: Culicidae) and anthropic environment. 5-Breeding of Anopheles albitarsis in flooded rice fields in south-eastern Brazil. Rev Saude Publica. 1994;28:329-31.

25. Forattini O, Kakitani I, Massad E, Marucci D. Studies on mosquitoes (Diptera: Culicidae) and anthropic environment. 2. Immature stages research at a rice irrigation system location in south-eastern Brazil. Rev Saude Publica. 1993;27:227-36.

26. Gbakima A. Inland valley swamp rice development: malaria, schistosomiasis, onchocerciasis in south central Sierra Leone. Public Health. 1994;108:149-57.

27. Georghiou GP. Studies on resistance to carbamate and organophosphorus insecticides in Anopheles albimanus. Am J Trop Med Hyg. 1972; 21:797-806.

28. Ghebreyesus TA, Haile M, Getachew A, Alemayehu T, Witten KH, Medhin A, et al. Pilot studies on the possible effects on malaria of small-scale irrigation dams in Tigray regional state, Ethiopia. J Public Health Med. 1998;20:238-40.

29. Ghebreyesus TA, Haile M, Witten KH, Getachew A, Yohannes A, Yohannes M, et al. Incidence of malaria among children living near dams in northern Ethiopia: community based incidence survey. BMJ. 1999;319(7211):663-6.

30. Giboda M, Pholsena K, Hongvanthong B, Gutvirth J, Rubik I. Malariometric survey in Keoudom District, Laos: sensitivity of Plasmodium falciparum to anti-malarials and automedication with chloroquine. Southeast Asian J Trop Med Public Health. 1992;23:383-8

31. Giglioli G. Ecological change as a factor in renewed malaria transmission in an eradicated area. A localized outbreak of $A$. aquasalis-transmitted malaria on the demerara river estuary, British Guiana, in the fifteenth year of A. darlingi and malaria eradication. Bull World Health Organ. 1963;29:131-45

32. Gillies MT, de Mellion B. The Anophelinae of Africa south of the Sahara (Ethiopian Zoogeographical Region). $2^{\text {nd }}$ ed. Johannesburg: South African Institute for Medical Research; 1968. (Publications of the South African Institute for Medical Research no.54)

33. Githeko A, Service M, Mbogo C, Atieli FK, Juma FO. Plasmodium falciparum sporozoite and entomological inoculation rates at the Ahero rice irrigation scheme and the Miwan sugar-belt in western Kenya. Ann Trop Med Parasitol. 1993;87:379-91.

34. Gomes AC, Paula MB, Duarte AM, Lima MA, Malafronte RS, Mucci LF, et al. Epidemiological and ecological aspects related to malaria in the area of influence of the lake at Porto Primavera dam, in western São Paulo State, Brazil. Rev Inst Med Trop Sao Paulo. 2008;50:287-95.

35. Gratz N. Emerging and resurging vector-borne diseases. Annu Rev Entomol. 1999;44:5175 .

36. Guimarães AE, Gentile C, Alencar J, Lopes CM, de Mello RP. Ecology of Anopheline (Diptera, Culicidae), malaria vectors around the Serra da Mesa Reservoir, State of Goiás, Brazil. 1. Frequency and climatic factors. Cad Saude Publica. 2004;20:291302 .

37. Guimarães AE, de Mello RP, Lopes CM, Alencar J, Gentile C. Prevalência de anofelinos (Diptera: Culicidae) no crepúsculo vespertino em áreas da usina hidrelétrica de Itaipu, no município de Guaíra, estado do Paraná, Brasil. Mem Inst Oswaldo Cruz. $1997 ; 92: 745-54$

38. Guthmann J, Llanos-Cuentas A, Palacios A, Hall AJ. Environmental factors as determinants of malaria risk. A descriptive study on the northern coast of Peru. Trop Med Int Health. 2002;7:518-25. 
SANCHEZ-RIBAS, J.; PARRA-HENAO, G. \& GUIMARÃES, A.E. - Impact of dams and irrigation schemes in Anopheline (Diptera:Culicidae) bionomics and malaria epidemiology. Rev. Inst. Med. Trop. Sao Paulo, 54(4): 179-91, 2012.

39. Hemingway J, Jayawardena KG, Herath PR. Pesticide resistance mechanisms produced by field selection pressures on Anopheles nigerrimus and A. culicifacies in Sri Lanka. Bull World Health Organ. 1986;64:753-8.

40. Henry MC, Rogier C, Nzeyimana I, Assi SB, Dossou-Yovo J, Audibert M, et al. Inland valley rice production systems and malaria infection and disease in the savannah of Côte d'Ivoire. Trop Med Int Health. 2003;8:449-58.

41. Hiwat H, Bretas G. Ecology of Anopheles darlingi Root with respect to vector importance: a review. Parasit Vectors. 2011;4:177.

42. Hunter JM, Rey L, Chu KY, Adekolu-John E, Mott K. Parasitic diseases in water resources development: the need for intersectoral negotiation. Geneva: World Health Organization; 1993.

43. Hunter JM, Rey L, Scott D. Man-made lakes and man-made diseases. Towards a policy resolution. Soc Sci Med. 1982;16:1127-45.

44. Ijumba JN, Lindsay SW. Impact of irrigation on malaria in Africa: paddies paradox. Med Vet Entomol. 2001;15:1-11.

45. Ijumba JN, Mosha FW, Lindsay SW. Malaria transmission risk variations derived from different agricultural practices in an irrigated area of northern Tanzania. Med Vet Entomol. 2002;16:28-38.

46. Ijumba JN, Mwangi RW, Beier JC. Malaria transmission potential of Anopheles mosquitoes in the Mwea-Tebere irrigation scheme, Kenya. Med Vet Entomol. $1990 ; 4: 425-32$

47. Jobin WR. Dams and disease: ecological design and health impacts of large dams, canals and irrigation systems. London: E \& FN Spon; 1999

48. Joyce S. Is it worth a dam? Environ Health Perspect. 1997;105:1050-5.

49. Keiser J, De Castro M, Maltese M, Bos R, Tanner M, Singer B, et al. Effect of irrigation and large dams on the burden of malaria on a global and regional scale. Am J Trop Med Hyg. 2005;72:392-406.

50. Keiser J, Utzinger J, Singer BH. The potential of intermittent irrigation for increasing rice yields, lowering water consumption, reducing methane emissions, and controlling malaria in African rice fields. J Am Mosq Control Assoc. 2002;18:329-40.

51. Klinkenberg E, van der Hoek W, Amerasinghe F. A malaria risk analysis in an irrigated area in Sri Lanka. Acta Trop. 2004;89:215-25.

52. Kobayashi J, Somboon P, Keomanila H, Inthavongsa S, Nambanya S, Inthakone S, et al. Malaria prevalence and a brief entomological survey in a village surrounded by rice fields in Khammouan province, Lao PDR. Trop Med Int Health. 2000;5:17-21.

53. Konradsen F, Stobberup KA, Sharma SK, Gulati OT, van der Hoek W. Irrigation water releases and Anopheles culicifacies abundance in Gujarat, India. Acta Trop. $1998 ; 71: 195-7$

54. Lacey LA, Lacey CM. The medical importance of riceland mosquitoes and their control using alternatives to chemical insecticides. J Am Mosq Control Assoc Suppl. 1990;2:193.

55. Lautze J, McCartney M, Kirshen P, Olana D, Jayasinghe G, Spielman A. Effect of a large dam on malaria risk: the Koka reservoir in Ethiopia. Trop Med Int Health. 2007; $12: 982-9$

56. Lindsay SW, Wilkins HA, Zieler HA, Daly RJ, Petrarca V, Byass P. Ability of Anopheles gambiae mosquitoes to transmit malaria during the dry and wet seasons in an area of irrigated rice cultivation in The Gambia. J Trop Med Hyg. 1991;94:313-24.

57. Lines JD. Do agricultural insecticides select for insecticide resistance in mosquitoes? A look at the evidence. Parasitol Today. 1988;4:S17-20.
58. Marrama L, Jambou R, Rakotoarivony I, Leong Pock Tsi JM, Duchemin JB, Laventure $\mathrm{S}$, et al. Malaria transmission in Southern Madagascar: influence of the environment and hydro-agricultural works in sub-arid and humid regions. Part 1. Entomological investigations. Acta Trop. 2004;89:193-203.

59. Mogi M. Effect of intermittent irrigation on mosquitoes (Diptera: Culicidae) and larvivorous predators in rice fields. J Med Entomol. 1993;30:309-19.

60. Molyneux D. Patterns of change in vector-borne diseases. Ann Trop Med Parasitol 1997;91:827-39.

61. Mouchet J, Manguin S, Sircoulon J, Laventure S, Faye O, Onapa A, et al. Evolution of malaria in Africa for the past 40 years: impact of climatic and human factors. J Am Mosq Control Assoc. 1998;14:121-30.

62. Mwangangi JM, Shililu J, Muturi EJ, Muriu S, Jacob B, Kabiru EW, et al. Anopheles larval abundance and diversity in three rice agro-village complexes Mwea irrigation scheme, central Kenya. Malar J. 2010;9:228.

63. Özer N. Emerging vector-borne diseases in a changing environment. Turk J Biol 2005;29:125-35

64. Parra-Henao G. Sistemas de información geográfica y sensores remotos. Aplicaciones en enfermedades transmitidas por vectores. Rev CES Med. 2010;24(2):75-89.

65. Quintero L, Thatcher B, Tadei WP. Biologia de anofelinos amazonicos. XXI. Ocorrência de espécies de Anopheles e outros culicideos na área de influência da hidrelétrica de Balbina - cinco anos após o enchimento do reservatório. Acta Amazonica. 1996;26:281-96

66. Ramasamy R, De Alwis R, Wijesundere A, Ramasamy MS. Malaria transmission at a new irrigation project in Sri Lanka: the emergence of Anopheles annularis as a major vector. Am J Trop Med Hyg. 1992;47:547-53.

67. Rezende HR, Sessa PA, Ferreira AL, Santos CB, Leite GR, Falqueto A. Efeitos da implantação da usina Hidrelétrica de Rosal, rio Itabapoana, estados do Espírito Santo e Rio de Janeiro, sobre anofelinos, planorbídeos e flebotomíneos. Rev Soc Bras Med Trop. 2009;42:160-4

68. Robert V, van den Broek A, Stevens P, Slootweg R, Petrarca V, Coluzzi M, et al Mosquitoes and malaria transmission in irrigated rice-fields in the Benoue valley of northern Cameroon. Acta Trop. 1992;52:201-4.

69. Rozendaal JA. Vector control: methods for use by individuals and communities. Geneva: World Health Organization; 1997

70. Rubio-Palis Y, Zimmerman R. Ecoregional classification of malaria vectors in the neotropics. J Med Entomol. 1997;34:499-510.

71. Sawyer D. Economic and social consequences of malaria in new colonization projects in Brazil. Soc Sci Med. 1993;37:1131-6.

72. Service MW. Rice, a challenge to health. Parasitol Today. 1989;5:162-5.

73. Service MW. Agricultural development and arthropod-borne diseases: a review. Rev Saude Publica. 1991;25:165-78

74. Sharma VP, Mehrotra KN. Return of malaria. Nature. 1982;298(5870):210.

75. Sharma VP, Srivastava A, Nagpal BM. A study of the relationship of rice cultivation and annual parasite incidence of malaria in India. Soc Sci Med. 1994;38:165-78.

76. Sharma S, Tyagi PK, Upadhyay AK, Haque MA, Adak T, Dash AP. Building small dams can decrease malaria: a comparative study from Sundargarh District, Orissa, India. Acta Trop. 2008;107:174-8.

77. da Silva-Nunes M, Moreno M, Conn JE, Gamboa D, Abeles S, Vinetz JM, et al. Amazonian malaria: asymptomatic human reservoirs, diagnostic challenges, environmentally driven changes in mosquito vector populations, and the mandate for sustainable control strategies. Acta Trop. 2012;121:281-91. 
78. Silva JS, Pacheco JB, Alencar J, Guimarães AE. Biodiversity and influence of climatic factors on mosquitoes (Diptera: Culicidae) around the Peixe Angical hydroelectric scheme in the state of Tocantins, Brazil. Mem Inst Oswaldo Cruz. 2010;105:155-62.

79. Singer BH, de Castro MC. Agricultural colonization and malaria on the Amazon frontier. Ann N Y Acad Sci. 2001;954:184-222.

80. Singh N, Mehra RK, Sharma VP. Malaria and the Narmada-river development in India: a case study of the Bargi dam. Ann Trop Med Parasitol. 1999;93:477-88.

81. Singh N, Mishra AK. Anopheline ecology and malaria transmission at a new irrigation project area (Bargi Dam) in Jabalpur (Central India). J Am Mosq Control Assoc. 2000; $16: 279-87$

82. Singh N, Shukla MM, Chand SK, Sharma VP. Outbreak of falciparum malaria in submerged villages of Narayanganj PHC, district Mandla due to Narmada Irrigation Project, Central India (Madhya Pradesh). Current Science. 1997;73:686-91.

83. Sleigh A, Jackson S. Dams, development, and health: a missed opportunity. Lancet. 2001;357:570-1

84. Snow W. Mosquito production and species succession from an area of irrigated rice fields in The Gambia, West Africa. J Trop Med Hyg. 1983;86:237-45.

85. Sornmani S, Vivatanasesth P, Bunnag T, Intarakhao C, Harinasuta C. A study on the pattern of socioeconomic and health status in relation to parasitic diseases in the inhabitants around Ubolratana Dam in northeast Thailand. Southeast Asian J Trop Med Public Health. 1973;4:421-34

86. Sow S, de Vlas SJ, Engels D, Gryseels B. Water-related disease patterns before and after the construction of the Diama dam in northern Senegal. Ann Trop Med Parasitol. 2002;96:575-86

87. Tadei WP, Dutary Thatcher B. Malaria vectors in the Brazilian Amazon: Anopheles of the subgenus Nyssorhynchus. Rev Inst Med Trop Sao Paulo. 2000;42:87-94.

88. Tadei WP, Thatcher BD, Santos JM, Scarpassa VM, Rodrigues IB, Rafael MS. Ecologic observations on anopheline vectors of malaria in the Brazilian Amazon. Am J Trop Med Hyg. 1998;59:325-35.

89. Teodoro U, Falavigna Guilherme AL, Lozovei A, La Salvia Filho V, Fukushigue Y, Spinosa RP, et al. Culicídeos do lago de Itaipu, no rio Paraná, Sul do Brasil. Rev Saúde Pública. 1995;29:6-14.

90. Tubaki R, Hashimoto S, Domingos M, Berenstein S. Abundance and frequency of culicids, emphasizing anophelines (Diptera, Culicidae), at Taquaruçu dam in the Paranapanema basin, southern Brazil. Rev Bras Entomol. 1999;43(3/4):173-84.

91. Tubaki RM, Menezes RM, Cardoso RP Jr, Bergo ES. Studies on entomological monitoring: mosquito species frequency in riverine habitats of the Igarapava Dam, Southern Region, Brazil. Rev Inst Med Trop Sao Paulo. 2004;46:223-9.
92. Tyagi B. A review of the emergence of Plasmodium falciparum-dominated malaria in irrigated areas of the Thar Desert, India. Acta Trop. 2004;89:227-39.

93. van der Hoek W, Amerasinghe F, Konradsen F, Amerasinghe PH. Characteristics of malaria vector breeding habitats in Sri Lanka: relevance for environmental management. Southeast Asian J Trop Med Public Health. 1998;29:168-72.

94. Vittor AY, Gilman RH, Tielsch J, Glass G, Shields T, Lozano W, et al. The effect of deforestation on the human-biting rate of Anopheles darlingi, the primary vector of Falciparum malaria in the Peruvian Amazon. Am J Trop Med Hyg. 2006;74:3-11.

95. Waddy BB. Research into the health problems of manmade lakes, with special reference to Africa. Trans R Soc Trop Med Hyg. 1975;69:39-50.

96. Walsh J, Molyneux D, Birley MH. Deforestation: effects on vector-borne disease. Parasitology. 1993;106(Suppl):S55-75.

97. WHO/FAO/UNEP/UNCHS Panel of Experts on Environmental Management for Vector Control. Agricultural development and vector-borne diseases: training and information materials on vector biology and control in the VBC. Slide set series. Geneva: World Health Organization; 1996.

98. World Health Organization. Manual on environmental management for mosquito control, with special emphasis on malaria vectors. Geneva: World Health Organization; 1982.

99. World Health Organization. Water Sanitation and Health Team, World Commission on Dams. Human health and dams: the World Health Organization's submission to the World Commission on Dams (WCD). Geneva: World Health Organization; 2000.

100. Yasuoka J, Levins R. Impact of deforestation and agricultural development on anopheline ecology and malaria epidemiology. Am J Trop Med Hyg. 2007;76:450-60.

101. Yewhalaw D, Legesse W, Van Bortel W, Gebre-Selassie S, Kloos H, Duchateau L, et al. Malaria and water resource development: the case of Gilgel-Gibe hydroelectric dam in Ethiopia. Malar J. 2009;8:21

102. Yohannes M, Haile M, Ghebreyesus T, Witten KH, Getachew A, Byass P, et al. Can source reduction of mosquito larval habitat reduce malaria transmission in Tigray, Ethiopia? Trop Med Int Health. 2005;10:1274-85.

103. Zeilhofer P, dos Santos ES, Ribeiro AL, Miyazaki RD, dos Santos M. Habitat suitability mapping of Anopheles darlingi in the surroundings of the Manso hydropower plant reservoir, Mato Grosso, Central Brazil. Int J Health Geogr. 2007;6:7.

Received: 17 February 2011

Accepted: 13 April 2012 


\section{Revista do Instituto de Medicina Tropical de São Paulo on line.}

Publications from 1987 to the present data are now available on:

http://www.scielo.br/rimtsp

PAST ISSUES 1959-1989 (PDF)

www.imt.usp.br/portal/

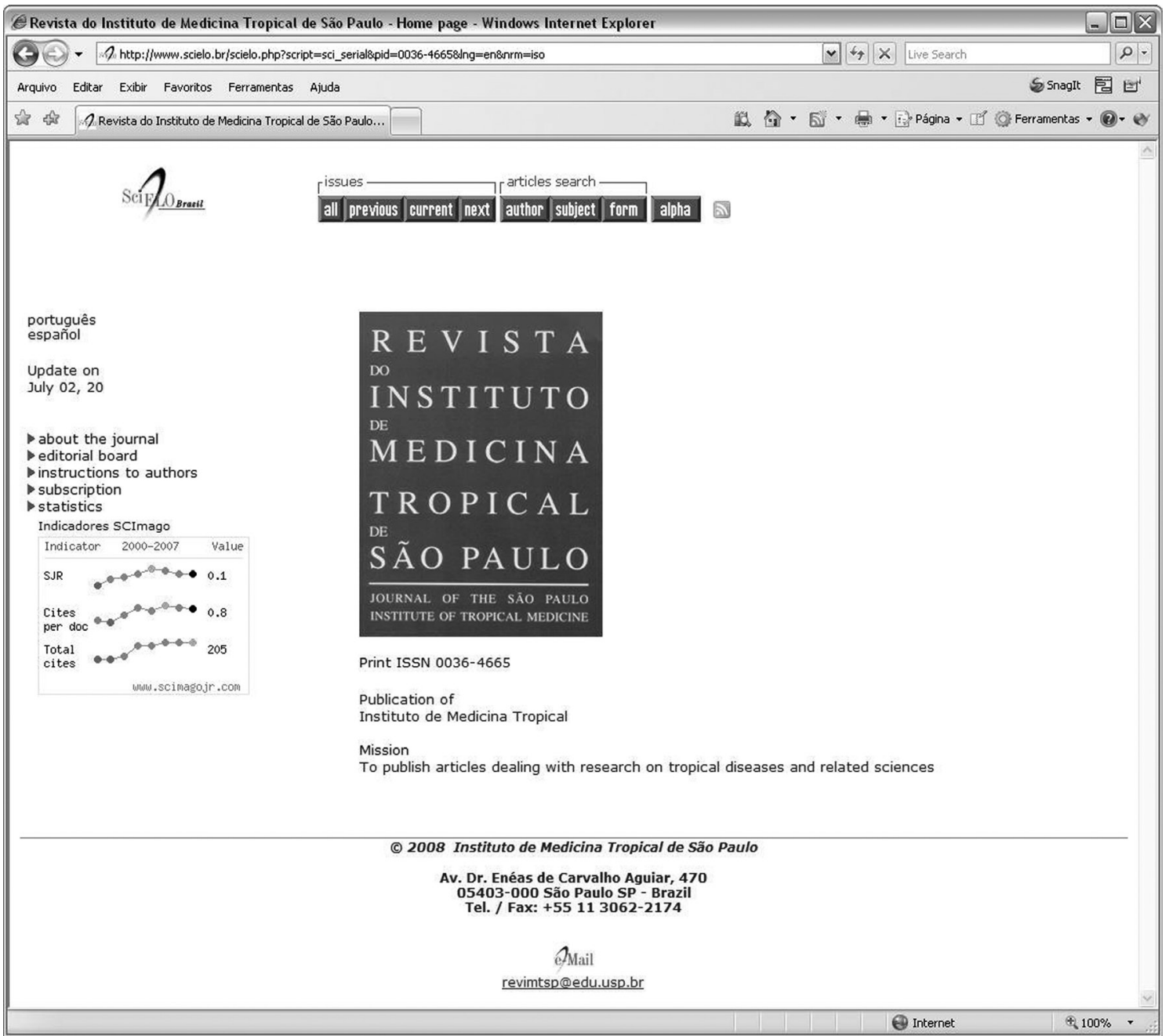

SciELO - The Scientific Electronic Library OnLine - SciELO is an electronic virtual covering a selected collection of Brazilian scientific journals.

The library is an integral part of a project being developed by FAPESP - Fundação de Amparo à Pesquisa do Estado de São Paulo, in partnership with BIREME - the Latin American and Caribbean Center on Health Sciences Information.

SciELO interface provides access to its serials collection via an alphabetic list of titles or a subject index or a search by word of serial titles, publisher names, city of publication and subject.

The interface also provides access to the full text of articles via author index or subject index or a search form on article elements such as author names, words from title, subject and words from full text.

FAPESP/BIREME Project on Scientific Electronic Publications Latin American and Caribbean Center on Health Sciences Information

Rua Botucatu 862 - 04023-901 São Paulo, SP - Brazil

Tel. (011) 5576-9863

scielo@bireme.br 